\title{
A Micro Analysis of Demand-side Determinants of Schooling in Urban Pakistan*
}

\author{
SHAHNAZ HAMID
}

\section{INTRODUCTION}

Investment in human capital is as important for growth as physical capital. The objective of this paper is to establish the importance of some factors, that affect the decision of a household to send their children who are of school going age, between 5-14 years, to school in urban areas.

This paper is divided into five sections, Section 2 reviews the relevant schooling literature for Pakistan. Section 3 points some theoretical hypotheses describing the data and Section 4 presents the analysis, and finally Section 5 presents some conclusions.

\section{A SUMMARY LITERATURE SURVEY OF THE DEMAND FOR SCHOOLING IN THE CONTEXT OF PAKISTAN}

So far in Pakistan, limited work has been done in this field. Irfan using the PLM $^{1}$ survey data, concluded that the socio-economic status of a household is positively related to children's schooling. However, this may be a limited explanation.

Lack of schools and socio-cultural norms also play an important role to keep children away from school, especially in the case of girls. Moreover, Irfan's analysis is limited to 10-14 years of age, whereas it is more important to examine the 5-9 years old age cohort.

Burney and Irfan again using the same PLM data set, carried out a more comprehensive analysis for both urban and rural Pakistan, and concluded that household income, parental education and tenurial status with respect to land has a positive impact on a household's decision to send a child to school.

We agree with the importance of parents' education, but consider that decisions taken by the head of the household also plays an important role, especially in case of girls.

received.

*Owing to unavoidable circumstances, the discussant's comments on this paper have not been Islamabad.

Shahnaz Hamid is Research Economist at the Pakistan Institute of Development Economics,

${ }^{1}$ Population, Labour Force and Migration. 


\section{DATA AND SOME HYPOTHESES}

Data

The present study is based on survey data, collected for the project Food Security Management in 1986 by Pakistan Instiute of Development Economics and International Food Policy Research Institute. Our analysis is based on 792 households, who have children in the age cohort 5-14 years.

\section{Hypotheses}

Our hypothesised model is that, the demand for child schooling is constrained by household socio-economic characteristics. ${ }^{2}$

Keeping in view four important variables, income' of the household, occupation, education and gender of household head, three different aspects of demand for child schooling will be analysed.

(a) Incidence of households sending children to school.

(b) Children attending school.

(c) ${ }^{3}$ A comparison between male and female children's schooling.

\section{Household Income}

Our major hypothesis is that poverty often compels the household to keep their children away from school.

To see the impact of household's income, we are taking into consideration, the total income of the household earned by all adult members in the age cohort above 14 years.

We are also analysing the impact of per capita income because aggregate figures for household income do not give a reliable estimate, and household size modifies the effect of income.

\section{Occupation}

For more diverse estimates of socio-economic status, we disaggregated income into two variables, occupation of the household head, and the periodicity of their earning, monthly, weekly, daily. Occupation of the head of household in general reflects the level of income as well as social class. Our hypothesis is that occupational status of household head and demand for children schooling have a positive relationship.

2This present study is a part of a larger, on-going project on "Why children do not go to school". Our major hypothesis for that study is that the household, the educational system, and opportunities for child labour, all together determine children's schooling.

${ }^{3}$ Due to aspace constraint this part has not been included in the paper: any one interested can obtain it from the author. 


\section{Education}

Occupation of the household head in general reflects their level of education. Education is important because of its impact on income and a bias towards children's education. Therefore, the educational level of the household head and children's schooling will also be positively related.

\section{Gender of the Household Head}

In a household, the head of the household has greater power in decisionmaking. In a household headed by a male, females will, therefore, have a lower decision-making power. Our hypothesis is that a lower proportion of children will go to school where household's head are males, especially in the case of female children because of prevalent social biases against women.

\section{EMPIRICAL RESULTS}

\section{Incidence of Household Sending their \\ Children to School}

\section{Household Income}

Our major hypothesis is that household income is positively related to child schooling. The first explanatory variable is total income of the household per month.

Table 1 shows that in the lowest income group, below < Rs.1000, the percentage of households sending all their children to school is lowest, at 33.7 percent. Households with a total monthly income of Rs $1000-<$ Rs $2000,41.2$

\section{Table 1}

Distribution of Households Sending their Children (5-14 Years of Age) to School by Household Income

\begin{tabular}{|c|c|c|c|c|c|c|}
\hline \multirow{2}{*}{$\begin{array}{l}\text { Total Income of } \\
\text { the Household } \\
\text { per Month } \\
\text { (in Rs) }\end{array}$} & \multicolumn{2}{|c|}{$\begin{array}{c}\text { Total Number of } \\
\text { Households Falling } \\
\text { in Category } \\
\end{array}$} & \multicolumn{2}{|c|}{$\begin{array}{l}\text { Households with } \\
\text { All Children } \\
\text { in School } \\
\end{array}$} & \multicolumn{2}{|c|}{$\begin{array}{l}\text { Household with At- } \\
\text { least One Child not } \\
\text { in School } \\
\end{array}$} \\
\hline & No. & $\%$ & No. & $\%$ & No. & $\%$ \\
\hline$<1000$ & 243 & 100.00 & 82 & 33.7 & 161 & 66.3 \\
\hline $1000<2000$ & 308 & 100.00 & 127 & 41.2 & 181 & 58.8 \\
\hline $2000<3000$ & 125 & 100.00 & 54 & 43.2 & 71 & 56.8 \\
\hline $3000<4000$ & 57 & 100.00 & 29 & 50.9 & 28 & 49.1 \\
\hline$>4000$ & 59 & 100.00 & 30 & 50.8 & 29 & 49.2 \\
\hline Total & 792 & 100.00 & 322 & 40.7 & 470 & 59.3 \\
\hline
\end{tabular}


percent send all their children to school. In the income group, Rs 2000-<3000, 43.2 percent of households send all their children to school. In the income group, Rs. $3000-<$ Rs $4000,50.9$ percent of the households send all their children to school. And for the highest income group, 50.8 percent of the households send all their children to school.

In keeping with this, another variable, households at least not sending one of their children to school, shows a negative relationship with household income. Our results support our hypothesis regarding income and child schooling.

Table 2 shows, that in the lowest per capita income group below Rs $<100$, only 32.4 percent of the households send all their children to school. Subsequently as the per capita income category increases the proportion of households sending all their children to school also rises from 32.3 percent to 54.3 percent. Table 2 makes it clear that as we move from the lowest per capita income group to a higher one, the percentage of households with at least one child not in school drops from 67.6 percent to 45.6 percent. Thus supporting our hypothesis regarding monthly per capita income.

\section{Table 2}

Distribution of Households Sending their Children (5-14 Years of Age) to School by per Capita Income per Month

\begin{tabular}{|c|c|c|c|c|c|c|}
\hline \multirow{2}{*}{$\begin{array}{l}\text { Household per- } \\
\text { Capita Income } \\
\text { per Month } \\
\text { (in Rs) }\end{array}$} & \multicolumn{2}{|c|}{$\begin{array}{c}\text { Total Number of } \\
\text { Households Falling } \\
\text { in Category }\end{array}$} & \multicolumn{2}{|c|}{$\begin{array}{l}\text { Households with } \\
\text { All Children } \\
\text { in School } \\
\end{array}$} & \multicolumn{2}{|c|}{$\begin{array}{l}\text { Household with At- } \\
\text { least One Child not } \\
\text { in School }\end{array}$} \\
\hline & No. & $\%$ & No. & $\%$ & No. & $\%$ \\
\hline$<100$ & 148 & 100.00 & 48 & 32.4 & 100 & 67.6 \\
\hline $100<200$ & 332 & 100.00 & 124 & 37.3 & 208 & 62.7 \\
\hline $200<300$ & 148 & 100.00 & 64 & 43.2 & 84 & 56.8 \\
\hline $300<400$ & 85 & 100.00 & 43 & 50.6 & 42 & 49.4 \\
\hline$>400$ & 79 & 100.00 & 43 & 54.4 & 36 & 45.6 \\
\hline$\overline{\text { Total }}$ & 792 & 100.00 & 322 & 40.66 & 470 & 59.34 \\
\hline
\end{tabular}

\section{Household Heads' Occupation and Periodicity of their Earning}

To analyse our hypothesis regarding occupational status, we have a value judgement, that occupation of the head of the household can be ranked in the following way. The highest status is for government employees, followed by private employees, the self-employed, the sick and labourers. We can not give any value judgement to undefined occupational status. The table show that the percentage of household with all children in school decreases from 58.6 percent to 43.2 percent, 
38.5 percent, 36.0 percent, 22.8 percent with a change in the occupational status of the household head from government employee to labour and vice versa (Table 3 ).

The above evidence supports our hypothesis that the household head's occupational status is positively related to households with all children in school.

Periodicity of household heads' earning reflects stability in the job, income and socio-economic status of a household. So our hypothesis is that, periodicity of household heads' earning will affect the household's demand for child schooling. Households in which the household head has a stable and reliable source of earning, the demand for children's schooling will be higher.

Table 3

Distribution of Households Sending their Children to School by Household Head's Occupation

\begin{tabular}{|c|c|c|c|c|c|c|}
\hline \multirow{2}{*}{$\begin{array}{l}\text { Household } \\
\text { Heads' } \\
\text { Occupation }\end{array}$} & \multicolumn{2}{|c|}{$\begin{array}{c}\text { Total Number of } \\
\text { Households Falling } \\
\text { in Category }\end{array}$} & \multicolumn{2}{|c|}{$\begin{array}{l}\text { Households with } \\
\text { All Children } \\
\text { in School }\end{array}$} & \multicolumn{2}{|c|}{$\begin{array}{l}\text { Households with At- } \\
\text { least One Child not } \\
\text { in School }\end{array}$} \\
\hline & No. & $\%$ & No. & $\%$ & No. & $\%$ \\
\hline Govt Employee & 111 & $100.00^{\circ}$ & 65 & 58.6 & 46 & 41.4 \\
\hline Private Employee & 125 & 100.00 & 54 & 43.2 & 71 & 56.8 \\
\hline Self Employed & 268 & 100.00 & 102 & 38.05 & 166 & 61.94 \\
\hline Sick & 25 & 100.00 & 9 & 36.0 & 16 & 64.0 \\
\hline Labour & 101 & 100.00 & 23 & 22.8 & 78 & 77.2 \\
\hline Other & 11 & 100.00 & 7 & 63.6 & 4 & 36.4 \\
\hline At Home & 133 & 100.00 & 57 & 42.8 & 76 & 57.14 \\
\hline Students & 1 & 100.00 & 0 & 0.0 & 1 & 100.0 \\
\hline Total & 775 & 100.00 & 317 & 40.57 & 458 & 59.42 \\
\hline
\end{tabular}

We have a value judgement that the periodicity of earnings can be ranked in the following way. The highest status is for monthly income earning, followed by profit, weekly, daily irregular, doing nothing and in kind.

As shown in Table 4, the percentage of households with all children in school drops from 50.50 (monthly earner) to 32.45 in case of irregular sources of earning. Our ranking of household heads clearly supports our hypothesis, that the periodicity of the household head's earning is related to income, and uncertainty in household head's earning is positively related to households sending all their children to school.

\section{Education of Household Head}

Our next hypothesis is that the household head's educational level is positively related to children's schooling (Table 5).

It becomes clear that the percentage of households with all children in school increases from 29. 4 percent in the case of an illiterate household head to 83.3 percent where the educational level of household head is the highest i.e. university 


\section{Table 4}

Distribution of Households Sending their Children (Aged 5-14 Years) to School by Periodicity of Households' Earning

\begin{tabular}{|c|c|c|c|c|c|c|}
\hline \multirow{2}{*}{$\begin{array}{l}\text { Periodicity of } \\
\text { Household } \\
\text { Heads' Earning }\end{array}$} & \multicolumn{2}{|c|}{$\begin{array}{c}\text { Number of } \\
\text { Households Falling } \\
\text { in Category }\end{array}$} & \multicolumn{2}{|c|}{$\begin{array}{l}\text { Households with } \\
\text { All Children } \\
\text { in School }\end{array}$} & \multicolumn{2}{|c|}{$\begin{array}{l}\text { Households with At- } \\
\text { least One Child not } \\
\text { in School }\end{array}$} \\
\hline & No. & $\%$ & No. & $\%$ & No. & $\%$ \\
\hline Monthly & 206 & 100.00 & 104 & 50.50 & 102 & 49.51 \\
\hline Profit & 141 & 100.00 & 53 & 37.58 & 88 & 62.41 \\
\hline Weekly & 32 & 100.00 & 11 & 34.37 & 21 & 65.62 \\
\hline Daily & 108 & 100.00 & 37 & 34.3 & 71 & 65.70 \\
\hline Irregular & 114 & 100.00 & 37 & 32.45 & 77 & 67.54 \\
\hline Doing Nothing" & 168 & 100.00 & 72 & 42.9 & 96 & 57.10 \\
\hline In kind & 6 & 100.00 & 3 & 50.00 & 3 & 50.00 \\
\hline Total & 775 & 100.00 & 317 & 40.9 & 458 & 59.1 \\
\hline
\end{tabular}

"Retired, old, sick, unemployed etc.

Table 5

Distribution of Households Sending their School Going Age Children (Aged 5-14 Years) to School by Educational Level of Household Head

\begin{tabular}{|c|c|c|c|c|c|c|}
\hline \multirow{2}{*}{$\begin{array}{c}\text { Educational } \\
\text { Level of } \\
\text { Household Head } \\
\end{array}$} & \multicolumn{2}{|c|}{$\begin{array}{c}\begin{array}{c}\text { Total Number of } \\
\text { Households Falling } \\
\text { in Category }\end{array} \\
\end{array}$} & \multicolumn{2}{|c|}{$\begin{array}{c}\text { Households with } \\
\text { All Children } \\
\text { in School } \\
\end{array}$} & \multicolumn{2}{|c|}{$\begin{array}{l}\text { Households with At } \\
\text { least One Child not } \\
\text { in School } \\
\end{array}$} \\
\hline & No. & $\%$ & No. & $\%$ & No. & $\%$ \\
\hline Apprentices & 2 & 100.00 & 0 & 0.0 & 2 & 100.00 \\
\hline Illiterate & 337 & 100.00 & 99 & 29.4 & 238 & 70.6 \\
\hline Literate & 123 & 100.00 & 45 & 36.6 & 78 & 63.4 \\
\hline Primary & 131 & 100.00 & 53 & 40.5 & 78 & 59.5 \\
\hline Middle & 80 & 100.00 & 36 & 45.0 & 44 & 55.0 \\
\hline Secondary & 86 & 100.00 & 62 & 72.1 & 24 & 27.9 \\
\hline University & 30 & 100.00 & 25 & 83.3 & 5 & 16.7 \\
\hline Other & 3 & 100.00 & 2 & 66.7 & 1 & $33.3^{\circ}$ \\
\hline Total & 792 & 100.00 & 322 & 40.7 & 470 & 59.3 \\
\hline
\end{tabular}

education. Thus supporting our hypothesis of a positive relationship between the educational level of household head and households with all their children in school. The table shows an inverse relationship between the household head's educational level and households with at least one child out of school. 


\section{Gender of the Household's Head}

An hypothesis is constructed on the basis of our field observation, both from rural and urban Pakistan. Females realise the importance for education, but having no say in decision-making, can not impose their decision, especially in the case of girl.

The interesting results that emerges from Table 6 shows that among the households headed by males, 40 percent send all their children to school, whereas the percentage increases to 49.1 in case of female-headed households. On the other hand, households headed by males contained a higher percentage of households with at least one child not in school, while for female-headed household, it drops to 50.9 percent. Evidence suggest that households headed by females are more inclined to educate their children.

Table 6

Distribution of Households Sending their Children (Aged 5-14 Years) to School by Gender of the Household Head

\begin{tabular}{|c|c|c|c|c|c|c|}
\hline \multirow{2}{*}{$\begin{array}{c}\text { Gender of } \\
\text { the Household } \\
\text { Head }\end{array}$} & \multicolumn{2}{|c|}{$\begin{array}{c}\text { Total Number of } \\
\text { Households Falling } \\
\text { in Category }\end{array}$} & \multicolumn{2}{|c|}{$\begin{array}{c}\text { Households with } \\
\text { All Children } \\
\text { in School }\end{array}$} & \multicolumn{2}{|c|}{$\begin{array}{l}\text { Households with At } \\
\text { least One Child not } \\
\text { in School }\end{array}$} \\
\hline & No. & $\%$ & No. & $\%$ & No. & $\%$ \\
\hline Male & 737 & 100.00 & 295 & 40.0 & 442 & 60.00 \\
\hline Female & 55 & 100.00 & 27 & 49.1 & 28 & 50.9 \\
\hline$\overline{\text { Total }}$ & 792 & 100.00 & 332 & 40.7 & 470 & 59.3 \\
\hline
\end{tabular}

\section{Incidence of Child School Enrollment}

In the following section, we have tried another estimate of the variable to explain child school enrollment. We will explain child school enrollment with all our previous determinants.

\section{Household Income (Household Total and per Capita Income)}

Table 7 clearly shows, that as the total household income per month increases, child school enrollment also increases. In the table, the households having total income < Rs 1000 per month, only 56.6 percent of the total children are in school, enrollment increases with each income category, from 56.64 percent to 59.42 percent, 61.83 percent, 71.9 percent and 70.53 percent.

From Table 8 , it becomes obvious that as we move from the lowest per capita income group to the highest per capita income group the percentage of total children attending school also improves from 59.76 to 69.07 percent. 


\section{Table 7}

Distribution of School Going Children (Aged 5-14 Years) by Total per Month Income of the Household

\begin{tabular}{|c|c|c|c|c|c|c|}
\hline \multirow{2}{*}{$\begin{array}{l}\text { Total House- } \\
\text { hold Income } \\
\text { Rs (pm) }\end{array}$} & \multicolumn{2}{|c|}{$\begin{array}{l}\text { Total No. of Children } \\
\text { whose Household Falling } \\
\text { in Category }\end{array}$} & \multicolumn{2}{|c|}{$\begin{array}{l}\text { Children in Income } \\
\text { Category Going to } \\
\text { School }\end{array}$} & \multicolumn{2}{|c|}{$\begin{array}{l}\text { Children in Income } \\
\text { Category not Going } \\
\text { to School }\end{array}$} \\
\hline & No. & $\%$ & No. & $\%$ & No. & $\%$ \\
\hline$<1000$ & 708 & 100.00 & 401 & 56.64 & 307 & 43.36 \\
\hline $1000-<2000$ & 892 & 100.00 & 530 & 59.42 & 362 & 40.58 \\
\hline $2000-<3000$ & 372 & 100.00 & 230 & 61.83 & 142 & 38.17 \\
\hline $3000-<4000$ & 171 & 100.00 & 123 & 71.9 & 48 & 28.07 \\
\hline$>4000$ & 190 & 100.00 & 134 & 70.53 & 56 & 29.47 \\
\hline Total & 2333 & 100.00 & 1418 & 60.78 & 915 & 39.22 \\
\hline
\end{tabular}

Table 8

Distribution of School Going Children (Aged 5-14 Years) by per Capita Income of the Household per Month

\begin{tabular}{|c|c|c|c|c|c|c|}
\hline \multirow{2}{*}{$\begin{array}{l}\text { Household } \\
\text { per Capita } \\
\text { Income per } \\
\text { Month (in Rs) }\end{array}$} & \multicolumn{2}{|c|}{$\begin{array}{l}\text { Total No. of } \\
\text { Children Falling } \\
\text { in Category }\end{array}$} & \multicolumn{2}{|c|}{$\begin{array}{l}\text { Children in Income } \\
\text { Category Going to } \\
\text { School }\end{array}$} & \multicolumn{2}{|c|}{$\begin{array}{c}\text { Children in Income } \\
\text { Category not Going } \\
\text { to School }\end{array}$} \\
\hline & No. & $\%$ & No. & $\%$ & No. & $\%$ \\
\hline$<100$ & 579 & 100.00 & 346 & 59.76 & 233 & 40.24 \\
\hline $100-<200$ & 970 & 100.00 & 560 & 57.73 & 410 & 42.27 \\
\hline $200-<300$ & 381 & 100.00 & 234 & 61.42 & 147 & 38.58 \\
\hline $300-<400$ & 209 & 100.00 & 144 & 68.90 & 65 & 31.10 \\
\hline$>400$ & 194 & 100.00 & 134 & 69.07 & 60 & 30.93 \\
\hline Total & 2333 & 100.00 & 1418 & 60.78 & 915 & 39.2 \\
\hline
\end{tabular}

\section{Household Head's Occupation,}

\section{and Periodicity of Earning}

Table 9 presents the evidence for household head's occupational status, and child school enrollment. Households having occupational status i.e. government employee, gives the highest percentage i.e. 75.39 percent of child enrollment. Whereas the percentage of child enrollment drops down from 75.39 to 38.6 percent with a change in occupation status from government employee to labourer

Table 10 shows a positive relationship between the periodicity status of household head earning, and child school enrollment. This relationship is smooth, upto, where the periodicity status of the household head's earning is daily, for the irregular nature of periodicity status of household head earning the results are not very clear. 
Table 9

Distribution of School Going Children (Aged 5-14 Years) by Occupational Status of Household Head

\begin{tabular}{|c|c|c|c|c|c|c|}
\hline \multirow{2}{*}{$\begin{array}{l}\text { Household } \\
\text { Heads } \\
\text { Occupation }\end{array}$} & \multicolumn{2}{|c|}{$\begin{array}{l}\text { Total Children whose } \\
\text { Households Falling } \\
\text { in Category }\end{array}$} & \multicolumn{2}{|c|}{$\begin{array}{l}\text { Children in Occupational } \\
\text { Category Going to } \\
\text { School }\end{array}$} & \multicolumn{2}{|c|}{$\begin{array}{l}\text { Children in Occu- } \\
\text { pational Category } \\
\text { not Going to School }\end{array}$} \\
\hline & No. & $\%$ & No. & $\%$ & No. & $\%$ \\
\hline Govt. Employee & 317 & 100.00 & 239 & 75.39 & 78 & 24.61 \\
\hline Private Employee & 338 & 100.00 & 221 & 65.38 & 117 & 34.62 \\
\hline Self Employed & 826 & 100.00 & 498 & 60.29 & 328 & 39.71 \\
\hline Sick & 73 & 100.00 & 42 & 57.53 & 31 & 42.47 \\
\hline Labour & 259 & 100.00 & 100 & 38.61 & 159 & 61.39 \\
\hline Other & 31 & 100.00 & 21 & 67.74 & 10 & 32.26 \\
\hline At Home & 487 & 100.00 & 297 & 60.98 & 190 & 39.01 \\
\hline Students & 2 & 100.00 & 0 & 0.0 & 2 & 100.0 \\
\hline Total & 2333 & 100.00 & 1418 & 60.78 & 915 & 39.22 \\
\hline
\end{tabular}

Table 10

Distribution of Households Sending their Children (Aged 5-14 Years) by Periodicity of Household Heads' Earning

\begin{tabular}{|c|c|c|c|c|c|c|}
\hline \multirow{2}{*}{$\begin{array}{c}\text { Periodicity of } \\
\text { Household Head's } \\
\text { Earning }\end{array}$} & \multicolumn{2}{|c|}{$\begin{array}{c}\text { Total Children } \\
\text { whose Households } \\
\text { Falling in Category }\end{array}$} & \multicolumn{2}{|c|}{$\begin{array}{l}\text { Children Falling } \\
\text { in Category } \\
\text { Going to School }\end{array}$} & \multicolumn{2}{|c|}{$\begin{array}{l}\text { Children Falling in } \\
\text { Category not Going } \\
\text { to School }\end{array}$} \\
\hline & No. & $\%$ & No. & $\%$ & No. & $\%$ \\
\hline Monthly & 591 & 100.00 & 412 & 69.71 & 179 & 30.29 \\
\hline Profit & 419 & 100.00 & 263 & 62.76 & 156 & 37.23 \\
\hline Weekly & 87 & 100.00 & 51 & 58.62 & 36 & 41.37 \\
\hline Daily & 312 & 100.00 & 159 & 50.96 & 153 & 49.04 \\
\hline Irregular & 323 & 100.00 & 172 & 53.25 & 151 & 46.75 \\
\hline Doing Nothing. & 582 & 100.00 & 353 & 60.65 & 229 & 39.35 \\
\hline In Kind & 19 & 100.00 & 8 & 42.11 & 11 & 57.89 \\
\hline Total & 2333 & 100.00 & 1418 & 60.78 & 915 & 39.22 \\
\hline
\end{tabular}

But on the basis of other evidence we may say that, there is a positive relationship between periodicity status of household head's earning and child schooling.

\section{Educational Level of Household Head}

Table 11 presents the relationship between the household head's educational level and child school enrollment ratio. A look at Table 11 shows that there exists a positive relationship between the two. The increase in household head's educational 
level, the child school enrollment ratio also increases from 33.33 percent to 88.75 percent. Thus supporting our hypothesis concerning child school enrollment and household head's education.

So evidence clearly supports our hypothesis that child school enrollment is positively related to the household head's educational level.

\section{Table 11}

Distribution of School Going Children (Aged 5-14 Years) by Educational Level of Household Head

\begin{tabular}{|c|c|c|c|c|c|c|}
\hline \multirow{2}{*}{$\begin{array}{l}\text { Educational } \\
\text { Level of House- } \\
\text { hold Head }\end{array}$} & \multicolumn{2}{|c|}{$\begin{array}{c}\text { Total Children whose } \\
\text { Households Falling } \\
\text { in Category }\end{array}$} & \multicolumn{2}{|c|}{$\begin{array}{c}\text { Children in } \\
\text { Category } \\
\text { Going to School } \\
\end{array}$} & \multicolumn{2}{|c|}{$\begin{array}{l}\text { Children in } \\
\text { Category not Going } \\
\text { to School }\end{array}$} \\
\hline & No. & $\%$ & No. & $\%$ & No. & $\%$ \\
\hline Apprentices & 3 & 100.00 & 1 & 33.33 & 2 & 66.67 \\
\hline Illiterate & 992 & 100.00 & 481 & 48.49 & 511 & 51.51 \\
\hline Literate & 347 & 100.00 & 210 & 60.52 & 137 & 39.48 \\
\hline Primary & 383 & 100.00 & 241 & 62.92 & 142 & 37.08 \\
\hline Middle & 263 & 100.00 & 194 & 73.76 & 69 & 26.24 \\
\hline Secondary & 255 & 100.00 & 211 & 82.75 & 44 & 17.25 \\
\hline University & 80 & 100.00 & 71 & 88.75 & 9 & 11.25 \\
\hline Other & 10 & 100.00 & 9 & 90.00 & 1 & 10.00 \\
\hline Total & 2333 & 100.00 & 1418 & 60.78 & 915 & 39.22 \\
\hline
\end{tabular}

\section{Household Heads Gender}

Table 12 shows the relationship of households headed by males and females to child schooling. Table 12 shows the positive impact of female-headed Table 12

Distribution of School Going Children (Aged 5-14 Years) by Household Head's Gender

\begin{tabular}{|c|c|c|c|c|c|c|}
\hline \multirow{2}{*}{$\begin{array}{c}\text { Gender of the } \\
\text { Household } \\
\text { Head }\end{array}$} & \multicolumn{2}{|c|}{$\begin{array}{c}\text { Total Children } \\
\text { whose Households } \\
\text { Falling in Category }\end{array}$} & \multicolumn{2}{|c|}{$\begin{array}{c}\text { Children in } \\
\text { Category } \\
\text { Going to School }\end{array}$} & \multicolumn{2}{|c|}{$\begin{array}{c}\text { Children in } \\
\text { Category not } \\
\text { Going to School }\end{array}$} \\
\hline & No. & $\%$ & No. & $\%$ & No. & $\%$ \\
\hline$\overline{\text { Male }}$ & 2166 & 100.00 & 1299 & 59.97 & 867 & 40.03 \\
\hline Female & 167 & 100.00 & 119 & 71.25 & 48 & 28.74 \\
\hline Total & 2333 & 100.00 & 1418 & 66.78 & 915 & 39.22 \\
\hline
\end{tabular}


households, on child school enrollment. As can be seen, households headed by a male had a 59.97 percent enrollment ratio, while households headed by a female had a 71.25 percent enrollment ratio. So the evidence supports our hypothesis that households headed by a female will be more inclined to send their children to school.

\section{CONCLUSION}

The present study suggests that poverty is the key determinant of demand for child schooling. Various manifestations of poverty, such as the low income of households, low occupational status of the household head; periodicity of household head's earning, and low level of household head's education, together with household economy dominated by a male, play an important role in constraining the demand for children's schooling.

\section{REFERENCES}

Burney, Nadeem A., and M. Irfan (1991) Parental Characteristics, Supply of Schools, and Child School Enrolment in Pakistan. The Pakistan Development Review 30:1.

Irfan, M. (1980) Poverty and Household Demographic Behaviour in Pakistan: Insights from PLM Survey 1979. Islamabad: Pakistan Institute of Development Economics. (PLM Project Report No. 11.) 